\title{
Effects of Crop Rotation and Irrigation on Verticillium dahliae Microsclerotia in Soil and Wilt in Cauliflower
}

\author{
C. L. Xiao, K. V. Subbarao, K. F. Schulbach, and S. T. Koike
}

First and second authors: Department of Plant Pathology, University of California, Davis, c/o USDA Agricultural Research Station, Salinas 93905; and third and fourth authors: University of California Cooperative Extension, Salinas 93901.

Current address of C. L. Xiao: Department of Plant Pathology, University of California, One Shields Avenue, Davis 95616.

Accepted for publication 8 June 1998.

\begin{abstract}
Xiao, C. L., Subbarao, K. V., Schulbach, K. F., and Koike, S. T. 1998. Effects of crop rotation and irrigation on Verticillium dahliae microsclerotia in soil and wilt in cauliflower. Phytopathology 88:1046-1055.

Experiments were conducted in field plots to evaluate the effects of broccoli residue on population dynamics of Verticillium dahliae in soil and on Verticillium wilt development on cauliflower under furrow and subsurface-drip irrigation and three irrigation regimes in 1994 and 1995. Treatments were a factorial combination of three main plots (broccoli crop grown, harvested, and residue incorporated in $V$. dahliae-infested plots; no broccoli crop or residue in infested plots; and fumigated control plots), two subplots (furrow and subsurface-drip irrigation), and three sub-subplots (deficit, moderate, and excessive irrigation regimes) arranged in a split-split-plot design with three replications. Soil samples collected at various times were assayed for $V$. dahliae propagules using the modified Anderson sampler technique. Incidence and severity of Verticillium wilt on cauliflower were assessed at 7- to 10-day intervals beginning a

after residue incorporation and continued to decline throughout the cauliflower season. The overall reduction in the number of propagules after two broccoli crops was approximately $94 \%$, in contrast to the fivefold increase in the number of propagules in infested main plots without broccoli after two cauliflower crops. Disease incidence and severity were both reduced approximately $50 \%(P<0.05)$ in broccoli treatments compared with no broccoli treatments. Differences between furrow and subsurfacedrip irrigation were not significant, but incidence and severity were significantly $(P<0.05)$ lower in the deficit irrigation regime compared with the other two regimes. Abundance of microsclerotia of $V$. dahliae on cauliflower roots about 8 weeks after cauliflower harvest was significantly $(P<$ $0.05)$ lower in treatments with broccoli compared with treatments without broccoli. Rotating broccoli with cauliflower and incorporating broccoli residues into the soils is a novel means of managing Verticillium wilt on cauliflower and perhaps on other susceptible crops. This practice would be successful regardless of the irrigation methods or regimes followed on the susceptible crops.
\end{abstract} month after cauliflower transplanting and continuing until harvest. Number of propagules in all broccoli plots declined significantly $(P<0.05)$

Verticillium dahliae Kleb. is a widely distributed soilborne pathogen causing vascular wilt diseases on more than 160 plant species and can survive in soil as microsclerotia for nearly 13 years $(33,34)$. Since 1990, Verticillium wilt has become a serious threat to cauliflower (Brassica oleracea L. var. botrytis L.) (23).

Management of Verticillium wilt in various crops has depended on a variety of techniques. In general, these techniques attempt to reduce $V$. dahliae microsclerotia in soil to levels below which the disease does not develop on susceptible crops. Since genetic resistance is not available in nearly all hosts of $V$. dahliae, the most common techniques employed for reducing microsclerotia are chemical and cultural $(9,10,18,20,26,37)$. Pending restrictions on methyl bromide, commonly used in combination with chloropicrin for propagule reduction, have also stimulated a search for alternative methods of Verticillium wilt control.

Crop rotation is one of the cultural techniques recommended to reduce $V$. dahliae microsclerotia in soil and to reduce Verticillium wilt in certain crops. Crop rotation rarely is able to eradicate the $V$. dahliae microsclerotia, because of its wide host range and the persistence of microsclerotia in soil at levels that can cause significant crop losses $(9,29)$. For crop rotation to be effective on persistent pathogens such as $V$. dahliae, the crop chosen for rotation with the susceptible crop should (i) result in a reduction of microsclerotia in soil and a concomitant reduction of wilt in the susceptible crop;

Corresponding author: K. V. Subbarao, E-mail address: kvsubbarao@ucdavis.edu

Publication no. P-1998-0810-01R

(C) 1998 The American Phytopathological Society
Additional keywords: crucifer residue, soilborne pathogen. (ii) be compatible with current production practices; and (iii) result in grower acceptance of the crop for rotation. Previous crop rotation studies on Verticillium wilt have not been successful in identifying crops that possess the above attributes, and these studies have also resulted in less than satisfactory control $(9,29)$.

The disease-suppressive effects of certain crucifer residues are well documented $(7,22,27,30,31)$ and are partially related to the breakdown products of glucosinolates, the characteristic sulfur-containing constituents of the members of the family Brassicaceae (24). This phenomenon has long been recognized, but has not resulted in successful adaptation for soilborne disease management by growers. Even though both cauliflower and broccoli are members of the family Brassicaceae, surveys of commercial production fields have not identified Verticillium wilt on broccoli even in soil heavily infested with inoculum (23), and isolates from cauliflower are only weakly pathogenic on broccoli (34). The number of $V$. dahliae microsclerotia was reduced by broccoli residue amendment in both growth chamber and greenhouse experiments, with fresh broccoli resulting in a significantly greater reduction than dry tissue (35). This finding was extrapolated to the field, and $V$. dahliae microsclerotia in soil and Verticillium wilt on cauliflower were reduced (36). Since broccoli has shown the potential to reduce $V$. dahliae propagules in soil and is already widely cultivated in California, it is an ideal candidate for use in rotation with a susceptible crop.

Because crops are cultivated under different irrigation methods, it is critical to understand how Verticillium wilt develops under these irrigation methods with and without crop rotation. Such information would also facilitate wider acceptance of this practice by growers. The relationship between wilt development and irrigation 
or soil moisture has been studied in other crops, and the results have been equivocal $(4-6,8,11,16,28)$. For example, on maple and mint, Verticillium wilt is more severe under moisture stress than under excessive moisture conditions $(6,28)$. In contrast, increased soil moisture increases wilt development in cotton (11). In potato, wilt severity was higher in furrow-irrigated compared with sprinklerirrigated fields (8), and potato early dying was more severe under excessive than under moderate or deficit irrigation regimes $(4,5)$.

The objectives of this study were to evaluate the effect of broccoli-cauliflower rotation on the dynamics of $V$. dahliae microsclerotia in soil and on Verticillium wilt development in cauliflower and to determine the development of Verticillium wilt on cauliflower with and without rotations with broccoli under deficit, moderate, and excessive irrigation regimes within furrow and subsurface-drip irrigation. A preliminary report has been published (38).

\section{MATERIALS AND METHODS}

Field plots. All experiments were conducted at the United States Department of Agriculture, Agricultural Research Station in Salinas, $\mathrm{CA}$, on an Antioch sandy loam (sand, $45.8 \%$; silt, $43.4 \%$; clay, $8.8 \%$; and organic matter, $1.8 \%$ ) with a $\mathrm{pH}$ of 6.1 . Prior to the experiment, all plots were fumigated with a mixture of methyl bromide and chloropicrin (50:50, vol/vol) at $444 \mathrm{~kg} / \mathrm{ha}$ in 1994 . The experimental design was a $3 \times 2 \times 3$ factorial combination of treatments arranged in a split-split-plot design with three replications. Main plots were a broccoli crop in $V$. dahliae-infested plots (each year spring broccoli was followed by summer cauliflower), no broccoli crop in infested plots (fallowed during spring, but planted to summer cauliflower), and fumigated control (only summer cauliflower planted each year). The subplots were furrow and subsurface-drip irrigation, and the sub-subplots were deficit, moderate, and excessive irrigation regimes. Each sub-subplot was six beds wide ( $1 \mathrm{~m}$ between bed centers) and $9 \mathrm{~m}$ long. The subplots were separated by $2 \mathrm{~m}$ and the main plots by $6 \mathrm{~m}$ of bare soil to reduce plot interactions.

Inoculum production. Erlenmeyer flasks (125 ml), each containing $50 \mathrm{ml}$ of potato dextrose broth, were inoculated with two 4-mmdiameter disks taken from a 4-week-old cauliflower $V$. dahliae isolate growing on potato dextrose agar. Flasks were incubated on a horizontal shaker for 2 weeks at room temperature $\left(22\right.$ to $\left.24^{\circ} \mathrm{C}\right)$, and the resulting conidial suspension was filtered through cheesecloth and adjusted to about $10^{7}$ conidia per ml using a hemacytometer. Field soil was sieved $(0.425 \mathrm{~mm})$ and sterilized by autoclaving at $121^{\circ} \mathrm{C}$ for $1 \mathrm{~h}$ on two successive days. Aliquots of $50 \mathrm{~g}$ were placed in 100- by $15-\mathrm{mm}$ glass petri plates, amended with $20 \mathrm{ml}$ of conidial suspension, and incubated on a laboratory bench at room temperature $\left(22\right.$ to $24^{\circ} \mathrm{C}$ ) for 10 days. Soil was then air-dried for 15 days. Microsclerotia thus produced were thoroughly mixed with naturally $V$. dahliae-infested soil from a commercial cauliflower field and used as inoculum carriers for infestation of field plots. The central four beds of each sub-subplot in the V. dahliae-infested main plots were infested using a Marvin incorporator to mix inoculum to a depth of $25 \mathrm{~cm}$.

Broccoli crop and residue incorporation. In both 1994 and 1995, the broccoli cultivar Greenbelt was direct-seeded in two rows per bed during mid-January in all of the 18 sub-subplots of the corresponding main plot. Plants were thinned to a spacing of $20 \mathrm{~cm}$ 3 weeks after emergence, and the crop was managed according to commercial practices (1). Prior to harvest, 10 randomly chosen plants from each sub-subplot were uprooted and washed free of soil. The stem and taproot of each plant were longitudinally split and examined for vascular necrosis characteristic of Verticillium wilt symptoms. Pieces of surface-sterilized root tissue from five plants were plated on sodium polypectate agar (NP-10) selective medium and incubated at room temperature $\left(22\right.$ to $\left.24^{\circ} \mathrm{C}\right)$. Plates were examined periodically for the development of $V$. dahliae colonies.
All marketable broccoli heads were harvested and discarded, and remaining residue was flail-shredded and incorporated $48 \mathrm{~h}$ later into the beds on 8 June 1994 and 3 June 1995, respectively. Comparable tillage operations were also conducted in all the sub-subplots of the $V$. dahliae-infested main plot without broccoli during the same time.

Cauliflower crop. Beds in all plots, including fallow, were reworked for cauliflower transplanting 2 to 4 weeks after residue incorporation. Transplants of susceptible cauliflower cv. White Rock (5 weeks old) were planted in all plots in single rows with a $25-\mathrm{cm}$ spacing on 24 June 1994 and 5 July 1995. Sprinklers irrigated all plots for 10 days to facilitate transplant establishment, after which the different irrigation treatments were begun. Frequency and amount of water applied for each irrigation method and regimes within methods were calculated based on the crop coefficients for cauliflower and evapotranspiration rates for the Salinas area (1). For furrow-irrigated plots, water was applied once every 4, 8, and 12 days for excessive, moderate, and deficit treatments, respectively. For subsurface-drip irrigation, water was applied every other day, twice a week, and once a week for excessive, moderate, and deficit treatments, respectively.

The crop was managed according to commercial recommendations for cauliflower (1). In furrow-irrigated plots, a urea-nitrate fertilizer (Wilbur-Ellis Co., Salinas, CA) was applied at the rate of $124 \mathrm{~kg} / \mathrm{ha}$ at 3 -week intervals. Plots were irrigated immediately after fertilization. In subsurface-drip-irrigated plots, a liquid formulation of nitrogen was applied through the irrigation system at rates similar to the furrow system.

In each plot, soil moisture was recorded using gypsum blocks (Soil Moisture Equipment Corp., Santa Barbara, CA) placed at 10and $25-\mathrm{cm}$ depths. The resistance of gypsum blocks was recorded at 2-day intervals and converted to water potential based on the charts provided by the manufacturer.

Soil sampling and assay. Soil samples from each sub-subplot were collected at broccoli harvest, cauliflower transplanting, and subsequently at 3-week intervals until the end of the cauliflower

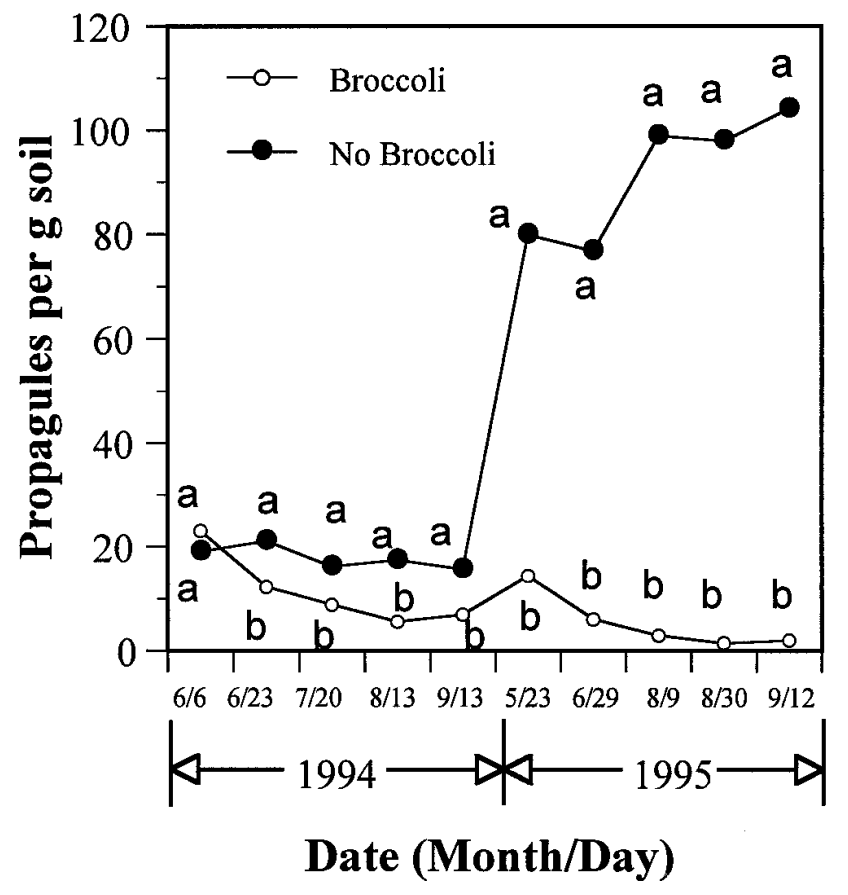

Fig. 1. Verticillium dahliae microsclerotia in soil in $V$. dahliae-infested plots with or without broccoli in 1994 and 1995. Broccoli residues were incorporated into the soil in the corresponding plots on 8 June 1994 and 3 June 1995, respectively. Different letters above or below each data point indicate significant differences within a sampling date according to a least significant difference test $(P<0.05)$. 
crop. Samples were taken with a 2.5 -cm-diameter probe to a depth of $15 \mathrm{~cm}$ from 12 random sites in the center four beds of each subsubplot and bulked. Each sample was placed in a paper bag and air-dried for 4 to 6 weeks on greenhouse benches. The soil was assayed for $V$. dahliae propagules by plating onto NP-10 medium using the modified Anderson sampler technique (2). Number of $V$. dahliae colonies was counted 4 weeks after plating and expressed as the number of propagules per gram of dry soil.

Disease assessment. Development of Verticillium wilt symptoms in cauliflower was assessed at 7- to 10-day intervals from a month after transplanting until crop maturity by collecting 10 plants from the center four beds in each sub-subplot. Plants were uprooted and washed free of soil; and then the stem and root portion was longitudinally split to visualize disease severity using a scale of 0 to 5 , in which $0=$ no discoloration, $1=1$ to $10 \%$ discoloration, $2=$ 11 to $30 \%$ discoloration, $3=31$ to $50 \%$ discoloration, $4=51$ to $75 \%$ discoloration, and $5=76$ to $100 \%$ discoloration of the vascular tissue. Pieces of diseased root and stem tissue from five plants were surface-sterilized, plated on NP-10 medium, and incubated at room temperature $\left(22\right.$ to $\left.24^{\circ} \mathrm{C}\right)$. Plates were examined periodically for the presence of $V$. dahliae colonies.

Nutrient analysis. In 1994 and 1995, 1 week prior to harvest, 10 petioles were randomly collected from upper fully expanded leaves of cauliflower plants from all sub-subplots to determine the nitrate in the different treatments. This was necessary to demonstrate that the observed results were not altered by the petiole nitrate concentration. Petiole samples were dried and analyzed for total extractable nitrate concentrations by conductimetric analysis (21).

Microsclerotia on cauliflower roots. Eight weeks after cauliflower harvest, 20 randomly chosen cauliflower stumps were uprooted from each sub-subplot. Roots were evaluated for both the presence and abundance of microsclerotia on roots. The latter was evaluated based on a 0 to 2 visual rating scale, in which $0=$ no microsclerotia, 1 = few microsclerotia, and 2 = abundant microsclerotia formed on roots.

Data analyses. Number of $V$. dahliae propagules per gram of soil was transformed as $\ln$ (propagules +1 ) prior to data analysis to normalize variance. Repeated measures analysis of variance was performed on the soil populations of $V$. dahliae from different sam- pling dates and Verticillium wilt incidence and severity over time. Repeated measures analysis of variance was performed using the SAS general linear models (GLM) procedure (release 6.11; SAS Institute, Inc., Cary, NC) with the REPEATED option. Time interactions were tested with Wilks' $\lambda$. Because the majority of disease incidence data from noninfested control plots was zero, only the data from treatments with and without broccoli in infested soil were included in the analysis. For final wilt incidence and severity data, however, analysis of variance was conducted on data from all treatments. Means were tested using a least significant difference (LSD) test $(P=0.05)$. Where interactions were significant, mean separations were performed using PROC Mixed procedure, in which pairwise comparisons of means using $t$ tests were obtained by the PDIFF option on the LEMEANS statement. To determine changes in the population of $V$. dahliae in soil, the overall percent increase was computed by dividing the number of propagules at the end of season by the number of propagules prior to broccoli incorporation, expressed as a percentage and analyzed by analysis of variance. Similarly, data on the abundance of microsclerotia formed on cauliflower roots and petiole nitrate concentrations also were analyzed by analysis of variance to determine treatment effects, and mean comparisons were made using the LSD test $(P=0.05)$.

\section{RESULTS}

Population dynamics of $\boldsymbol{V}$. dahliae in soil. In 1994, initial inoculum levels after artificial soil infestation were 23 and 19 propagules per $\mathrm{g}$ of soil in broccoli and no broccoli treatments, respectively, and were not significantly $(P>0.39)$ different (Fig. 1). Incorporation of broccoli residue significantly $(P<0.05)$ reduced the number of $V$. dahliae propagules in soil in both 1994 and 1995 experiments (Fig. 1). In 1994, the overall reduction in the number of propagules from 6 June to 13 September was approximately $70 \%$ in broccoli residue-incorporated plots compared with no significant changes in plots with no broccoli (Fig. 1). In 1995, the reduction in the number of propagules from 23 May to 30 August was about $90 \%$ in broccoli residue-incorporated plots compared with a $23 \%$ increase in plots with no broccoli. The combined reduction in the number of propagules over both 1994 and 1995 seasons from 6 June

TABLE 1. Repeated measures analysis of variance describing effects of soil amendments (broccoli residue in Verticillium dahliae-infested soil and no broccoli residue in $V$. dahliae-infested soil), irrigation methods (furrow and subsurface drip), and irrigation regimes (excessive, moderate, and deficit) on population dynamics of V. dahliae in soil in 1994 and 1995

\begin{tabular}{|c|c|c|c|c|c|c|c|c|}
\hline \multirow[b]{2}{*}{ Source of variation } & \multicolumn{4}{|c|}{1994} & \multicolumn{4}{|c|}{1995} \\
\hline & $\mathrm{df}^{\mathrm{w}}$ & $\mathrm{MS}^{\mathrm{x}}$ & $P>F^{\mathrm{y}}$ & Wilks' $\lambda$ & $\mathrm{df}$ & MS & $P>F$ & Wilks' $\lambda$ \\
\hline Block & 2 & 0.0096 & 0.7930 & $\ldots^{\mathrm{z}}$ & 2 & 0.4893 & 0.0983 & $\ldots$ \\
\hline Soil amendment (soil) & 1 & 15.2284 & 0.0061 & $\ldots$ & 1 & 393.2493 & 0.0033 & $\ldots$ \\
\hline Block $\times$ soil $\left(\right.$ error $\left._{\mathrm{a}}\right)$ & 2 & 0.0940 & $\ldots$ & $\ldots$ & 2 & 1.3183 & $\ldots$ & $\ldots$ \\
\hline Irrigation methods (irrigation) & 1 & 0.0017 & 0.9344 & $\ldots$ & 1 & 0.8953 & 0.1567 & $\ldots$ \\
\hline Soil $\times$ irrigation & 1 & 0.4289 & 0.2351 & $\ldots$ & 1 & 0.2790 & 0.3862 & $\ldots$ \\
\hline Block $\times$ irrigation (soil) $\left(\right.$ error $_{b}$ ) & 4 & 0.2200 & $\ldots$ & $\ldots$ & 4 & 0.2955 & $\ldots$ & $\ldots$ \\
\hline Irrigation regimes (regime) & 2 & 0.0665 & 0.2285 & $\ldots$ & 2 & 1.2749 & 0.0065 & $\ldots$ \\
\hline Soil $\times$ regime & 2 & 0.0702 & 0.2120 & $\ldots$ & 2 & 0.3498 & 0.1784 & $\ldots$ \\
\hline Irrigation $\times$ regime & 2 & 0.3327 & 0.0037 & $\ldots$ & 2 & 0.7762 & 0.0327 & $\ldots$ \\
\hline Soil $\times$ irrigation $\times$ regime & 2 & 0.1961 & 0.0236 & $\ldots$ & 2 & 0.1684 & 0.4164 & $\ldots$ \\
\hline Residual (error ${ }_{c}$ ) & 16 & 0.0410 & $\ldots$ & $\ldots$ & 16 & 0.1819 & $\ldots$ & $\ldots$ \\
\hline \multicolumn{9}{|l|}{ Time effects } \\
\hline Time & 4 & $\ldots$ & 0.0001 & 0.146 & 4 & $\ldots$ & 0.0001 & 0.074 \\
\hline Time $\times$ block & 8 & $\ldots$ & 0.6460 & 0.659 & 8 & $\ldots$ & 0.1777 & 0.452 \\
\hline Time $\times$ soil & 4 & $\ldots$ & 0.0002 & 0.204 & 4 & $\ldots$ & 0.0001 & 0.057 \\
\hline Time $\times$ irrigation & 4 & $\ldots$ & 0.1166 & 0.006 & 4 & $\ldots$ & 0.3915 & 0.071 \\
\hline Time $\times$ soil $\times$ irrigation & 4 & $\ldots$ & 0.0575 & 0.001 & 4 & $\ldots$ & 0.2365 & 0.025 \\
\hline Time $\times$ regime & 8 & $\ldots$ & 0.4473 & 0.579 & 8 & $\ldots$ & 0.7803 & 0.718 \\
\hline Time $\times$ soil $\times$ regime & 8 & $\ldots$ & 0.9571 & 0.835 & 8 & $\ldots$ & 0.0987 & 0.394 \\
\hline Time $\times$ irrigation $\times$ regime & 8 & $\ldots$ & 0.4881 & 0.596 & 8 & $\ldots$ & 0.3697 & 0.547 \\
\hline Time $\times$ soil $\times$ irrigation $\times$ regime & 8 & $\ldots$ & 0.4924 & 0.598 & 8 & $\ldots$ & 0.1207 & 0.413 \\
\hline
\end{tabular}

${ }^{\mathrm{w}}$ Degrees of freedom.

x Mean square.

y The significant probability values associated with the $F$ tests.

$\mathrm{z} \ldots=$ Not determined. 
1994 to 30 August 1995 was about $94 \%$ in broccoli residue-incorporated plots. In contrast, the number of propagules in soil with no broccoli increased approximately five times. After the first cauliflower crop, the number of propagules increased in all infested plots, because of the abundant microsclerotia formed on cauliflower roots. In broccoli residue-incorporated plots, there was also a marginal increase in the number of propagules after the cauliflower crop in 1994 owing to the limited microsclerotia formed on cauliflower roots. The propagules in these plots, however, decreased to one to two propagules per $\mathrm{g}$ of dry soil by the end of the 1995 cauliflower crop that followed the second incorporation of broccoli residue (Fig. 1).

Repeated measures analysis of variance indicated that soil populations of $V$. dahliae between infested plots with and without broccoli were significantly $(P<0.05)$ different both in 1994 and 1995 seasons (Table 1). The irrigation methods imposed on the subsequent cauliflower crop and the irrigation $\times$ soil amendment (main plots) and irrigation regime $\times$ soil amendment interactions did not affect the soil populations of $V$. dahliae (Table 1). These results were consistent during both years. The time effects and time $\times$ soil amendment (main plots) interaction significantly $(P<0.05)$ affected the populations of $V$. dahliae (Table 1). The slopes between broccoli and no broccoli treatments over time were significantly different.

To evaluate the effects of irrigation on the dynamics of $V$. dahliae in soil, soil moisture in each sub-subplot was monitored throughout the cauliflower cropping season. In 1994, furrow soil water potentials ranged from -0.037 to $-1.235,-0.034$ to -0.875 , and -0.021 to $-0.058 \mathrm{MPa}$ for deficit, moderate, and excessive regimes, respectively; for subsurface-drip irrigation, the values ranged from -0.027 to $-1.288,-0.021$ to -0.514 , and -0.019 to $-0.291 \mathrm{MPa}$ for deficit, moderate, and excessive regimes, respectively (Fig. 2). The average values of water potential under three irrigation regimes were within the ranges that favor pathogen activity (19). The overall increase (or reduction) in the number of propagules within a year was not significantly different among irrigation regimes in both 1994 and 1995 (Fig. 3). The overall percentage change in the number of propagules was significantly lower in furrow than in subsurfacedrip irrigation in 1994. However, it was not significantly different between irrigation methods in 1995 (data not shown).

Effects on Verticillium wilt. During both seasons, none of the broccoli plants examined exhibited Verticillium wilt symptoms. The fungus also was not recovered from any of the plated tissue.

Repeated measures analysis of variance indicated that time effects and time $\times$ soil amendment (main plots) interactions were significant $(P<0.05)$ for both incidence and severity of Verticillium wilt (except for time $\times$ soil amendment interaction for incidence in 1995) (Table 2). Time $\times$ irrigation interaction was not significant $(P>0.05)$ (except for incidence in 1995); however, time $\times$ irrigation regime interaction was significant for wilt severity only in 1995 (Table 2).

Analysis of variance of the final wilt incidence and severity showed a significant effect of the main plot treatments and irrigation regimes (Table 3 ). Both final wilt incidence and severity were significantly lower in treatments with broccoli compared with treatments without broccoli in 1994 and 1995 (Figs. 4 and 5). Disease incidence and severity were both reduced approximately $50 \%$ in plots with broccoli compared with plots with no broccoli. Final disease incidence and severity, respectively, were $43.8 \%$ and 0.87 in plots with broccoli, $84.7 \%$ and 1.77 in plots with no broccoli, and $0.69 \%$ and 0.01 in fumigated control in 1994 (Fig. 4). Final disease incidence and severity, respectively, were $45.1 \%$ and 1.12 in plots with broccoli, $77.8 \%$ and 2.42 in plots with no broccoli, and $1.67 \%$ and 0.05 in fumigated control in 1995 (Fig. 5).

The final wilt incidence was not significantly $(P>0.05)$ different between furrow and subsurface-drip irrigation in both 1994 and 1995 (Table 3). In 1994, final wilt severity was not significantly different $(P>0.05)$ between irrigation methods (Table 3). In 1995, soil amendment $\times$ irrigation interaction was significant for wilt severity (Table 3). The difference in final severity between the two irrigation methods only occurred in infested plots with no broccoli (data not shown), wherein the final wilt severity was significantly $(P<0.05)$ higher in subsurface-drip than in furrow irrigation.

Final wilt incidence was lower $(P<0.05)$ in the deficit compared with moderate and excessive irrigation regimes in both 1994 and 1995 (Table 3; Figs. 4 and 5). Differences between moderate and excessive regimes, however, were not significant, and there was no soil amendment $\times$ irrigation regime interaction (Table 3; Figs. 4 and 5). In 1994, soil amendment $\times$ irrigation regimes interaction was observed $(P<0.05)$ for wilt severity (Table 3$)$. The final wilt severity was lower $(P<0.05)$ in infested plots without broccoli in the deficit compared with the moderate and excessive irrigation

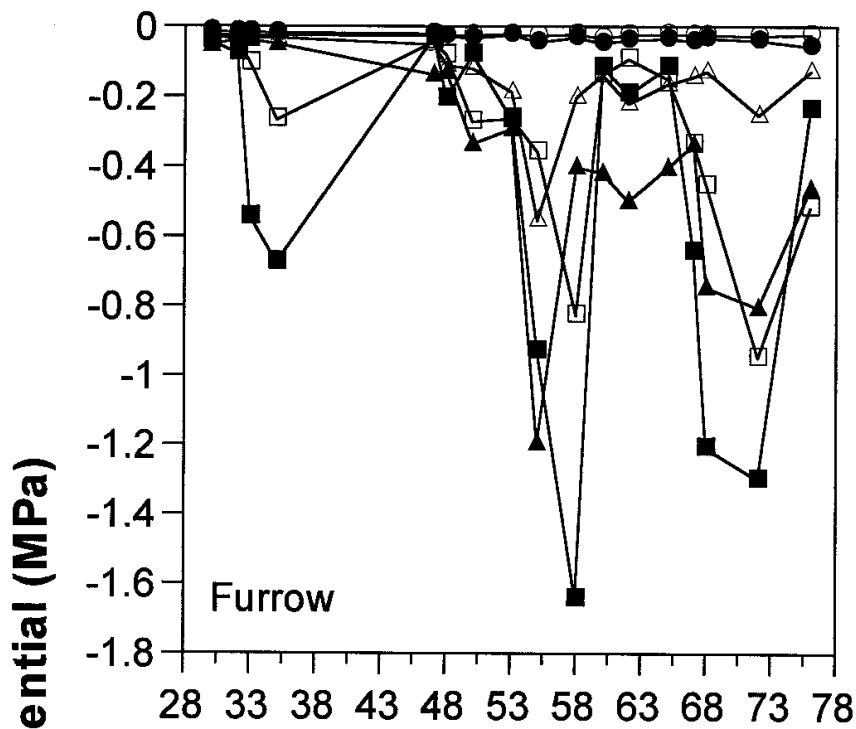

\&

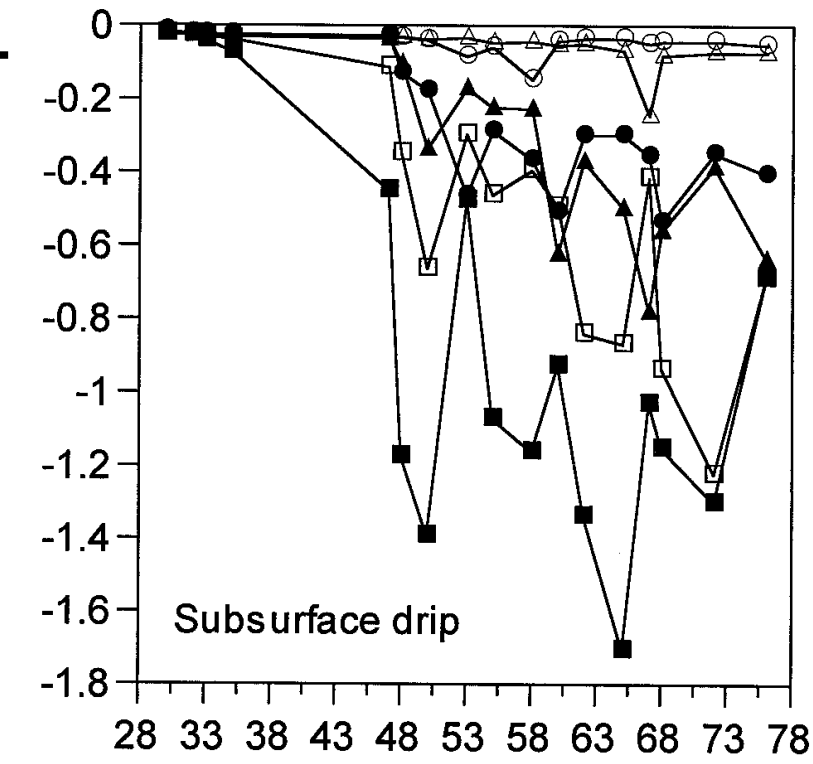

Days after transplanting

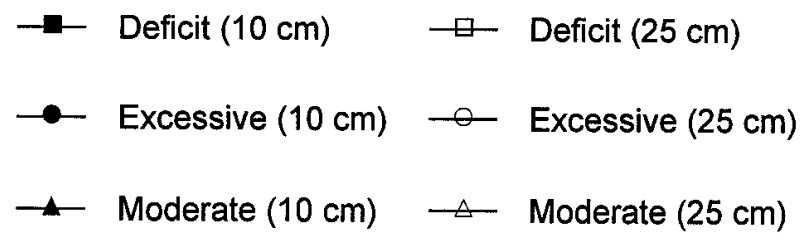

Fig. 2. Soil moisture potential under furrow and subsurface-drip irrigation with deficit, moderate, and excessive regimes in cauliflower field plots. Gypsum blocks were placed at $10-$ and $25-\mathrm{cm}$ depths. Each point is the average of nine readings. 
regimes. Differences between moderate and excessive regimes were not significant (Figs. 4 and 5). In 1995, significant differences in final severity between irrigation regimes were detected in both broccoli and no broccoli treatments (Table 3), and final severity was lower in deficit than in other irrigation regimes (Figs. 4 and 5).

Petiole nutrient concentrations. Nitrate-nitrogen concentrations in petioles sampled at 1 week prior to harvest in the three main plots were not significantly different $(P<0.05)$ in both 1994 and 1995 (Table 4). In 1994, the nitrate concentrations in petioles were not different either between furrow and subsurface-drip irrigation or among three irrigation regimes. In 1995, however, the nitrate concentration in petioles from furrow-irrigated plots was significantly higher than in subsurface-drip-irrigated plots in petioles from the deficit regime compared with excessive and moderate irrigation regimes (Table 4). The values of nitrate concentrations for all treatments, however, were within the range for normal cauliflower growth (1).

Microsclerotia formation on roots. The percentage of root systems with one or more microsclerotia and abundance of microsclerotia formed on cauliflower roots about 8 weeks after harvest were significantly $(P<0.05)$ lower in plots with soil amendment compared with those with no amendment (Fig. 6). Irrigation methods had no effect on abundance of microsclerotia (data not shown). The percentage of root systems with microsclerotia, however, was significantly $(P<0.05)$ lower in the deficit compared with moderate and excessive irrigation regimes. But the difference between moderate and excessive regimes was not significantly different. There were also no significant $(P<0.05)$ differences between deficit, moderate, and excessive regimes for abundance of microsclerotia on the roots (Fig. 6).

\section{DISCUSSION}

Incorporation of broccoli residue reduced the number of $V$. dahliae propagules in soil and resulted in a reduction in incidence and severity of Verticillium wilt on cauliflower in our experimental plots. Greatest reduction in number of propagules occurred within 2 to 4 weeks after residue incorporation, but continued throughout the following cauliflower crop. The overall reduction in the population size of $V$. dahliae in soil and a tangible reduction in the disease incidence and severity occurred regardless of irrigation regimes

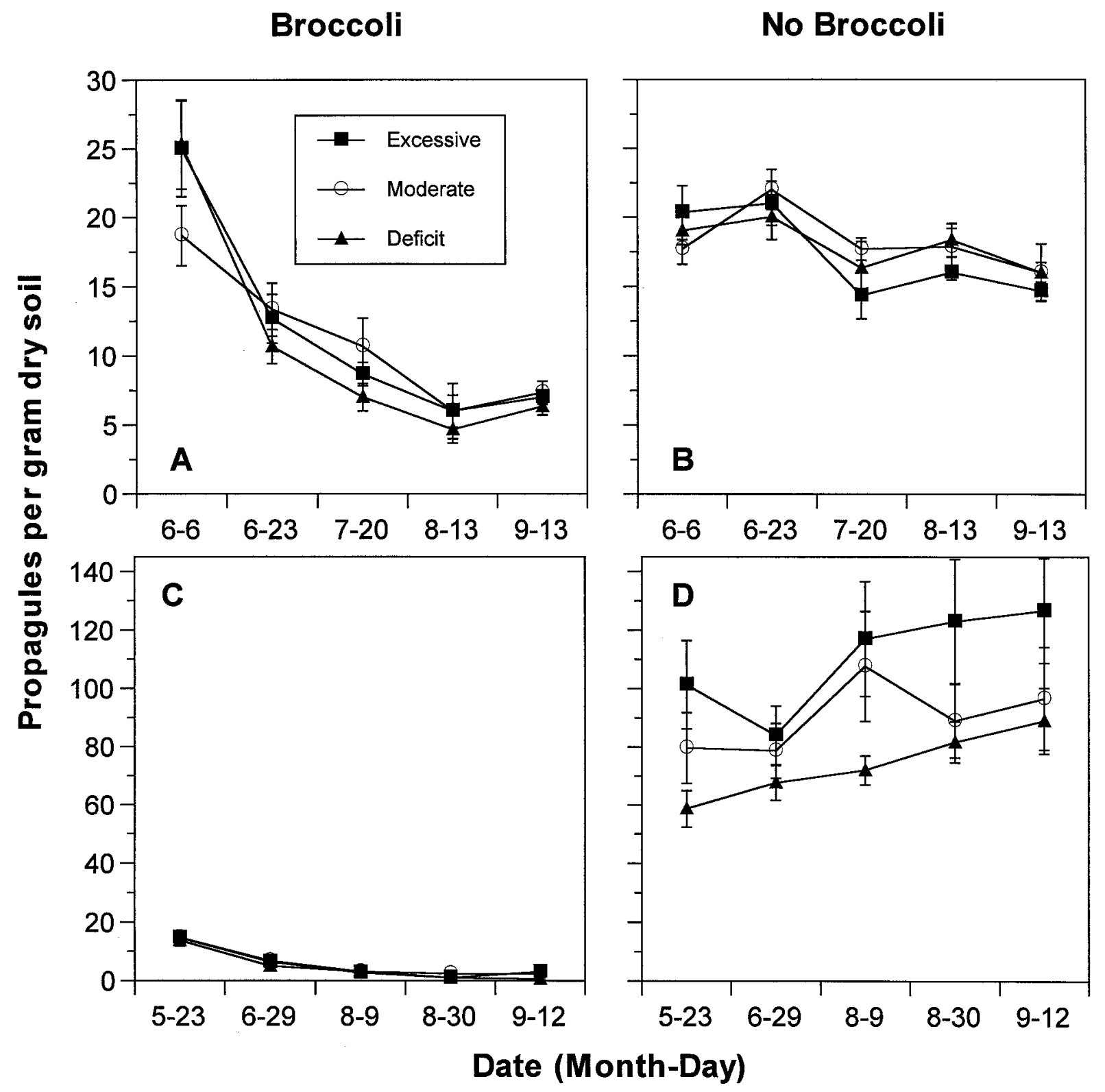

Fig. 3. Verticillium dahliae propagules in V. dahliae-infested plots with and without a broccoli amendment under excessive, moderate, and deficit irrigation regimes in A and B, 1994 and C and D, 1995. Broccoli residues were incorporated into the soil in the corresponding plots on 8 June 1994 and 3 June 1995, respectively. Vertical bars are the standard errors of the mean. 
practiced in the cauliflower crop. However, wilt incidence was highest in the excessive irrigation regime.

Reduction in the number of soilborne pathogen propagules by incorporation of a dry crucifer residue has been previously reported $(7,22,27,30,31)$. But the practice has not been adapted for Verticillium wilt control, because of the challenge of obtaining a large amount of dry cruciferous residue by growers. In our study, we have demonstrated that Verticillium wilt on cauliflower can be managed in coastal California by developing a rotation scheme that includes broccoli as a cash crop and then incorporating the broccoli residue into the soil. This rotation scheme also fits current cropping systems and can be easily adapted by growers in this area. Furthermore, potential losses of soil fumigants such as methyl bromide leave few alternatives for control of Verticillium wilt. Thus, rotation of susceptible crops with broccoli provides a potentially novel means to control $V$. dahliae elsewhere.

In our experimental plots, two crops of broccoli were required to reduce soil populations of $V$. dahliae from an initial level of 20 prop-

TABLE 2. Repeated measures analysis of variance describing effects of soil amendments (soil) including broccoli residue and no broccoli residue in Verticillium dahliae-infested soil; irrigation methods (irrigation) including furrow and subsurface drip; and irrigation regimes (regime) including excessive, moderate, and deficit on Verticillium wilt development on cauliflower in 1994 and 1995

\begin{tabular}{|c|c|c|c|c|c|c|c|}
\hline \multirow[b]{2}{*}{ Year } & \multirow[b]{2}{*}{ Source of variation } & \multicolumn{3}{|c|}{ Wilt incidence } & \multicolumn{3}{|c|}{ Wilt severity } \\
\hline & & $\mathrm{df}^{\mathrm{y}}$ & Wilks' $\lambda$ & $P>F^{\mathrm{z}}$ & $\mathrm{df}$ & Wilks' $\lambda$ & $P>F$ \\
\hline \multicolumn{8}{|l|}{1994} \\
\hline & Time & 4 & 0.035 & 0.0001 & 4 & 0.023 & 0.0001 \\
\hline & Time $\times$ block & 8 & 0.527 & 0.3238 & 8 & 0.225 & 0.0061 \\
\hline & Time $\times$ soil & 4 & 0.205 & 0.0002 & 4 & 0.128 & 0.0001 \\
\hline & Time $\times$ irrigation & 4 & 0.087 & 0.4295 & 4 & 0.623 & 0.9381 \\
\hline & Time $\times$ soil $\times$ irrigation & 4 & 0.919 & 0.9975 & 4 & 0.312 & 0.7507 \\
\hline & Time $\times$ regime & 8 & 0.669 & 0.6708 & 8 & 0.345 & 0.0530 \\
\hline & Time $\times$ soil $\times$ regime & 8 & 0.523 & 0.3148 & 8 & 0.153 & 0.0007 \\
\hline & Time $\times$ irrigation $\times$ regime & 8 & 0.365 & 0.0692 & 8 & 0.414 & 0.1233 \\
\hline & Time $\times$ soil $\times$ irrigation $\times$ regime & 8 & 0.483 & 0.2331 & 8 & 0.705 & 0.7533 \\
\hline \multicolumn{2}{|r|}{ 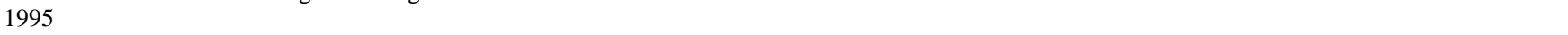 } & 4 & 0.034 & 0.0001 & 4 & 0.037 & 0.0001 \\
\hline & Time $\times$ block & 8 & 0.601 & 0.4990 & 8 & 0.710 & 0.7643 \\
\hline & Time $\times$ soil & 4 & 0.746 & 0.3946 & 4 & 0.321 & 0.0033 \\
\hline & Time $\times$ irrigation & 4 & 0.001 & 0.0354 & 4 & 0.059 & 0.3589 \\
\hline & Time $\times$ soil $\times$ irrigation & 4 & 0.025 & 0.2373 & 4 & 0.100 & 0.4594 \\
\hline & Time $\times$ regime & 8 & 0.462 & 0.1954 & 8 & 0.334 & 0.0457 \\
\hline & Time $\times$ soil $\times$ regime & 8 & 0.736 & 0.8168 & 8 & 0.573 & 0.4318 \\
\hline & Time $\times$ irrigation $\times$ regime & 8 & 0.749 & 0.8414 & 8 & 0.459 & 0.1906 \\
\hline & Time $\times$ soil $\times$ irrigation $\times$ regime & 8 & 0.461 & 0.1927 & 8 & 0.495 & 0.2568 \\
\hline
\end{tabular}

y Degrees of freedom.

$\mathrm{z}$ The significant probability values associated with the $F$ tests.

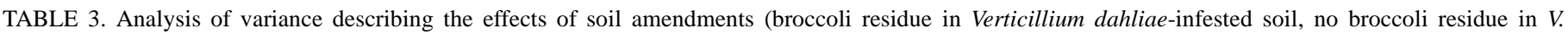

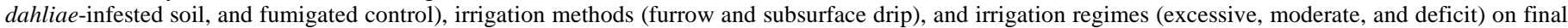
Verticillium wilt incidence and severity on cauliflower at the end of cropping season in 1994 and 1995

\begin{tabular}{|c|c|c|c|c|c|c|c|}
\hline \multirow[b]{2}{*}{ Year } & \multirow[b]{2}{*}{ Source of variation } & \multicolumn{3}{|c|}{ Wilt incidence } & \multicolumn{3}{|c|}{ Wilt severity } \\
\hline & & $\mathrm{df}^{\mathrm{w}}$ & $\mathrm{MS}^{\mathrm{x}}$ & $P>F^{\mathrm{y}}$ & df & MS & $P>F$ \\
\hline \multicolumn{8}{|l|}{1994} \\
\hline & Model & 29 & 0.2347 & 0.0001 & 29 & 1.1991 & 0.0001 \\
\hline & Block & 2 & 0.0061 & 0.7071 & 2 & 0.1901 & 0.2097 \\
\hline & Soil amendment (soil) & 2 & 3.1779 & 0.0001 & 2 & 14.0035 & 0.0001 \\
\hline & Block $\times$ soil $\left(\right.$ error $\left._{\mathrm{a}}\right)$ & 4 & 0.0161 & $\ldots{ }^{\mathrm{z}}$ & 4 & 0.0803 & $\ldots$ \\
\hline & Irrigation methods (irrigation) & 1 & 0.0012 & 0.7502 & 1 & 0.3544 & 0.0940 \\
\hline & Soil $\times$ irrigation & 2 & 0.0072 & 0.5354 & 2 & 0.2998 & 0.1059 \\
\hline & Block $\times$ irrigation (soil) $\left(\right.$ error $\left._{b}\right)$ & 6 & 0.0104 & $\ldots$ & 6 & 0.0897 & $\ldots$ \\
\hline & Irrigation regimes (regime) & 2 & 0.0425 & 0.0184 & 2 & 0.8238 & 0.0001 \\
\hline & Soil $\times$ regime & 4 & 0.0226 & 0.0680 & 4 & 0.6424 & 0.0001 \\
\hline & Irrigation $\times$ regime & 2 & 0.0037 & 0.6622 & 2 & 0.0402 & 0.4788 \\
\hline & Soil $\times$ irrigation $\times$ regime & 4 & 0.0281 & 0.0332 & 4 & 0.0689 & 0.2980 \\
\hline & Residual ( error $_{\mathrm{c}}$ ) & 24 & 0.0089 & $\ldots$ & 24 & 0.0529 & $\ldots$ \\
\hline \multicolumn{3}{|c|}{ 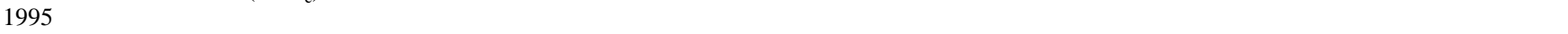 } & 0.2061 & 0.0001 & 29 & 2.1816 & 0.0001 \\
\hline & Block & 2 & 0.0113 & 0.1225 & 2 & 0.0729 & 0.7372 \\
\hline & Soil amendment (soil) & 2 & 2.6244 & 0.0001 & 2 & 25.2754 & 0.0003 \\
\hline & Block $\times$ soil $\left(\right.$ error $\left._{\mathrm{a}}\right)$ & 4 & 0.0030 & $\ldots$ & 4 & 0.2161 & $\ldots$ \\
\hline & Irrigation methods (irrigation) & 1 & 0.0403 & 0.1982 & 1 & 0.5202 & 0.0164 \\
\hline & Soil $\times$ irrigation & 2 & 0.0118 & 0.5722 & 2 & 0.2598 & 0.0449 \\
\hline & Block $\times$ irrigation (soil) $\left(\right.$ error $_{b}$ ) & 6 & 0.0193 & $\ldots$ & 6 & 0.0477 & $\ldots$ \\
\hline & Irrigation regimes (regime) & 2 & 0.1206 & 0.0039 & 2 & 2.0026 & 0.0023 \\
\hline & Soil $\times$ regime & 4 & 0.0369 & 0.1053 & 4 & 0.8177 & 0.0301 \\
\hline & Irrigation $\times$ regime & 2 & 0.0311 & 0.1844 & 2 & 0.7528 & 0.0709 \\
\hline & Soil $\times$ irrigation $\times$ regime & 4 & 0.0159 & 0.4635 & 4 & 0.3997 & 0.2139 \\
\hline & Residual ( error $_{\mathrm{c}}$ ) & 24 & 0.0171 & $\ldots$ & 24 & 0.2542 & $\ldots$ \\
\hline
\end{tabular}

\footnotetext{
${ }^{\mathrm{w}}$ Degrees of freedom.

x Mean square.

y The significant probability values associated with the $F$ tests.

$\mathrm{z} \ldots=$ Not determined.
} 
agules per $g$ of soil to 2 propagules per $g$ of soil. The required length of rotation of susceptible crops with broccoli may depend on the initial level of soil infestation and the relative susceptibility of the crop. In 1994, the density of $V$. dahliae propagules in soil decreased in plots with the broccoli crop. From the end of 1994 season to prior to broccoli residue incorporation in 1995, the number of propagules increased in all main plots infested with $V$. dahliae. This increase could be attributed to the microsclerotia formed on roots and other infected parts of cauliflower plant that remained in the soil after harvest and the resultant inoculum augmentation in the soil. The formation of microsclerotia on cauliflower root residues that were infected during the previous season or seasons continues, and the woody portions of the root tissues take longer than 8 weeks to decompose and release microsclerotia into soil. Correspondingly, in 1995, the number of propagules continued to increase in $V$. dahliae-infested plots without broccoli in contrast to the decrease in plots with broccoli. Continued formation of microsclerotia on root residues that were infected in the previous season may be responsible for this increase in $V$. dahliae-infested plots without broccoli.

Soil moisture affects production of $V$. dahliae microsclerotia in soil and in plant tissue $(17,19)$. Microsclerotia of $V$. dahliae multiply by sporulation when soil is air-dried and remoistened (12,25). In culture medium, production of $V$. dahliae microsclerotia either increases or remains unchanged at osmotic potential between -0.2 to $-2 \mathrm{MPa}$.
No microsclerotia were produced at osmotic values between -7 to $-8 \mathrm{MPa}$ (19). In V. dahliae-infected tomato stems, formation of microsclerotia was inhibited in saturated soil. These results, however, were observed at constant water potential conditions (19). In our study, the population dynamics of $V$. dahliae in soil was monitored in field plots under fluctuating soil moisture conditions. Different irrigation methods and regimes result in different soil water potential patterns. But the average values of water potential under three irrigation regimes were within the ranges that favor the pathogen activity (19). The overall percentage of increase or decrease in the soil propagules within a year in treatments with and without broccoli was not significantly different among irrigation regimes in both 1994 and 1995. This indicates that the irrigation frequency and amount of water applied did not account for the difference in population changes between the two main plot treatments.

Increased disease incidence and severity under wet soil conditions have been reported for other soilborne pathogens $(3,13,14,32)$. This relationship also has been documented on a potato- $V$. dahliae system $(4,5)$. In irrigated potato-production systems, disease severity of plants grown in $V$. dahliae-infested soil was greater under the excessive than under the moderate or deficit irrigation regimes $(4,5)$. In this study also, increased incidence and severity of Verticillium wilt on cauliflower were observed in moderate and excessive irrigation regimes. An excessive irrigation can lead to improved root growth throughout the soil profile, which may increase the

\section{Broccoli}
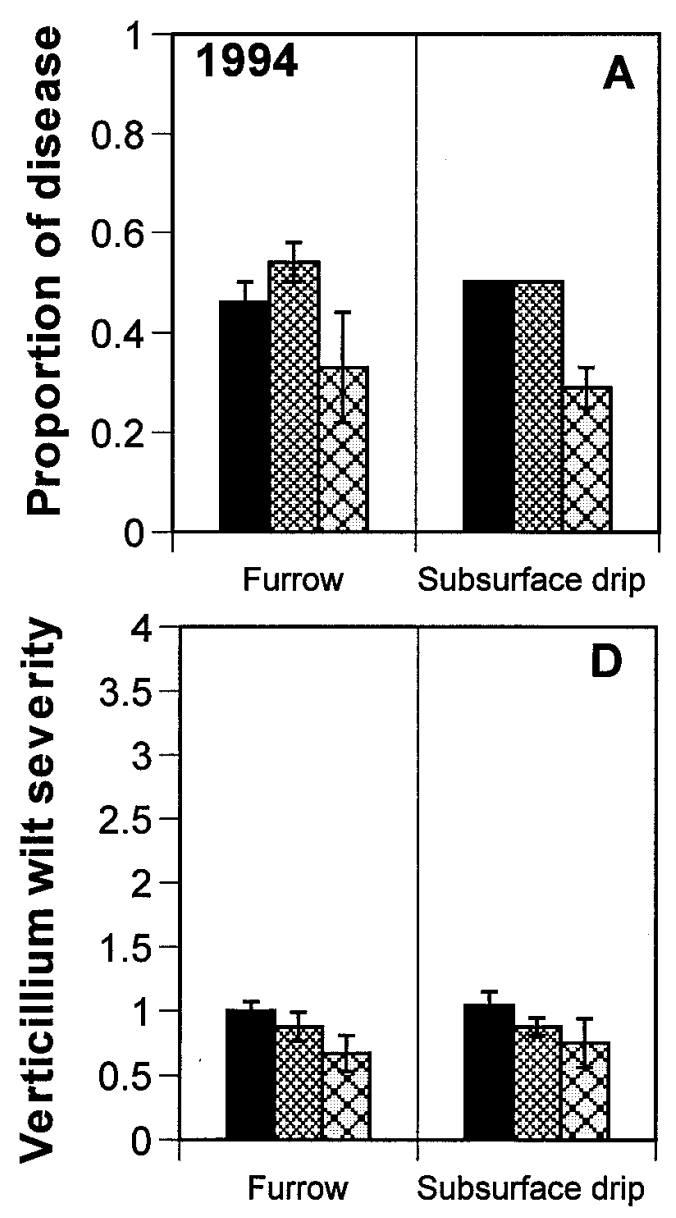

No Broccoli
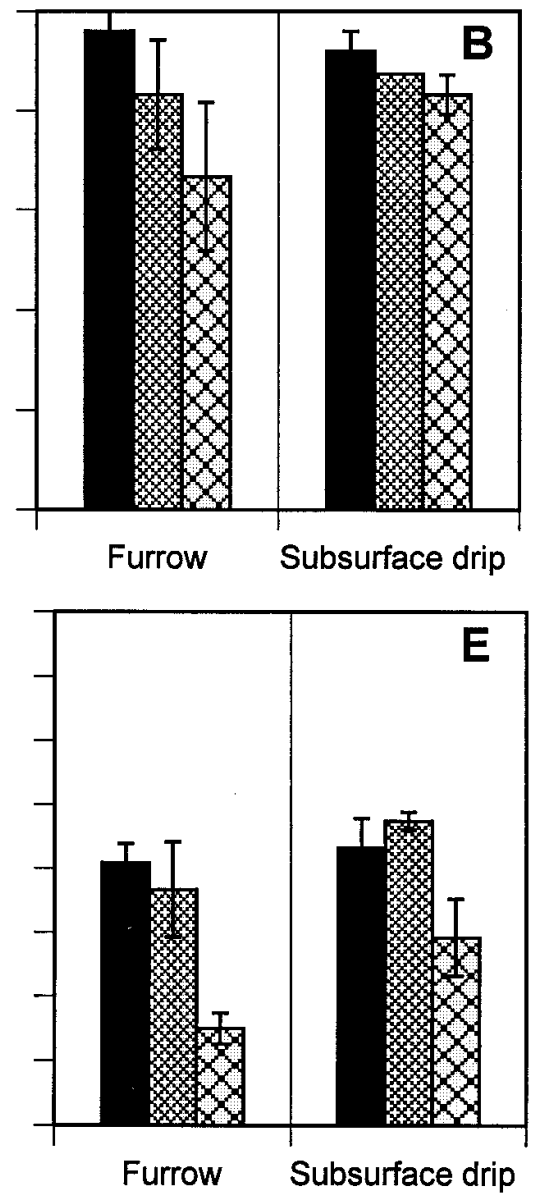

Irrigation
Fumigated control
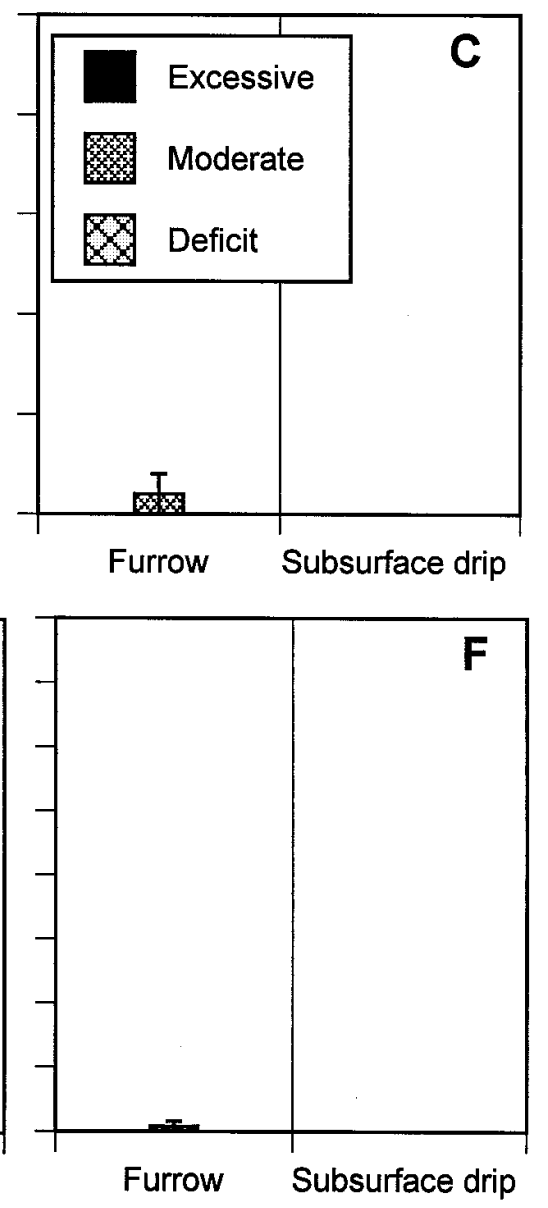

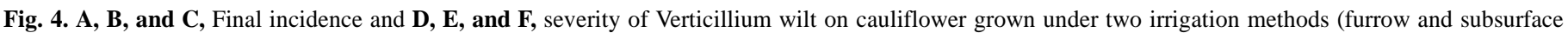

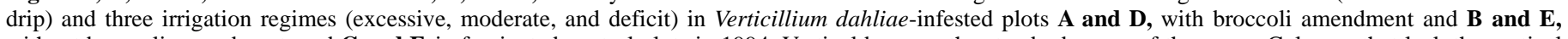

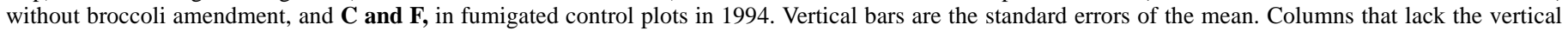
bars have a standard error of 0 . 
probability of contact with and infection by $V$. dahliae (4). Excessive irrigation also may have an effect on movement of conidia of $V$. dahliae from sporulating microsclerotia to the root surface and may increase the movement of the conidia in the vascular tissue, which would affect the rate of vascular colonization and wilt development $(5,29)$. In cauliflower, a higher root density in excessive irrigation regime than in moderate and deficit regimes was observed, which perhaps explains the higher wilt incidence and severity that occurred in this treatment (39).

In our experimental plots, cauliflower roots remained in the soil after the harvest; some diseased roots (determined by the presence of vascular necrosis) did not produce microsclerotia in treatments with broccoli compared with abundant microsclerotia produced on all diseased roots in V. dahliae-infested plots without broccoli. Formation of $V$. dahliae microsclerotia on infected plant parts of many field crops has been well documented $(18,19,26)$. Formation of microsclerotia on dying host debris in the soil can cause an increase in inoculum density in the following year, especially if the increase is greater than the reduction in microsclerotia due to mortality (18, 19,26). The lower level of microsclerotia formed on cauliflower roots suggested that broccoli residue incorporation could reduce not only the number of existing microsclerotia in soil, but also the inoculum that develops on infected cauliflower roots or on other susceptible crops. This prevention of soil inoculum augmentation allows not only repeated cultivation of cauliflower crops, but also reduces chemical inputs.

Crucifer residue-mediated suppression of soilborne pathogens due to toxic volatile compounds released during the decomposition in

TABLE 4. Petiole nitrate concentrations in cauliflower cv. White Rock in Verticillium dahliae-infested plots with and without broccoli residue and in fumigated control plots under different irrigation methods and regimes

\begin{tabular}{lcc}
\hline & \multicolumn{2}{c}{ Nitrate concentration $(\mathrm{ppm})^{\mathrm{z}}$} \\
\cline { 2 - 3 } & 1994 & 1995 \\
\hline Treatments & & \\
Broccoli $+V$. dahliae & $8052.8 \mathrm{a}$ & $5966.7 \mathrm{a}$ \\
No broccoli $+V$. dahliae & $7588.9 \mathrm{a}$ & $5599.4 \mathrm{a}$ \\
$\quad$ Fumigated control & $7111.1 \mathrm{a}$ & $4819.2 \mathrm{a}$ \\
Irrigation methods & & \\
$\quad$ Furrow & $7513.0 \mathrm{a}$ & $6553.5 \mathrm{a}$ \\
$\quad$ Subsurface drip & $7655.6 \mathrm{a}$ & $4370.0 \mathrm{~b}$ \\
Irrigation regimes & & \\
$\quad$ Deficit & $7772.2 \mathrm{a}$ & $6125.3 \mathrm{a}$ \\
Moderate & $7577.8 \mathrm{a}$ & $5251.7 \mathrm{~b}$ \\
Excessive & $7402.8 \mathrm{a}$ & $5008.3 \mathrm{~b}$ \\
\hline
\end{tabular}

$\mathrm{z}$ Numbers followed by the same letters are not significantly different within each column according to a least significant difference test $(P \leq 0.05)$. Each figure is the mean of three replications per year.

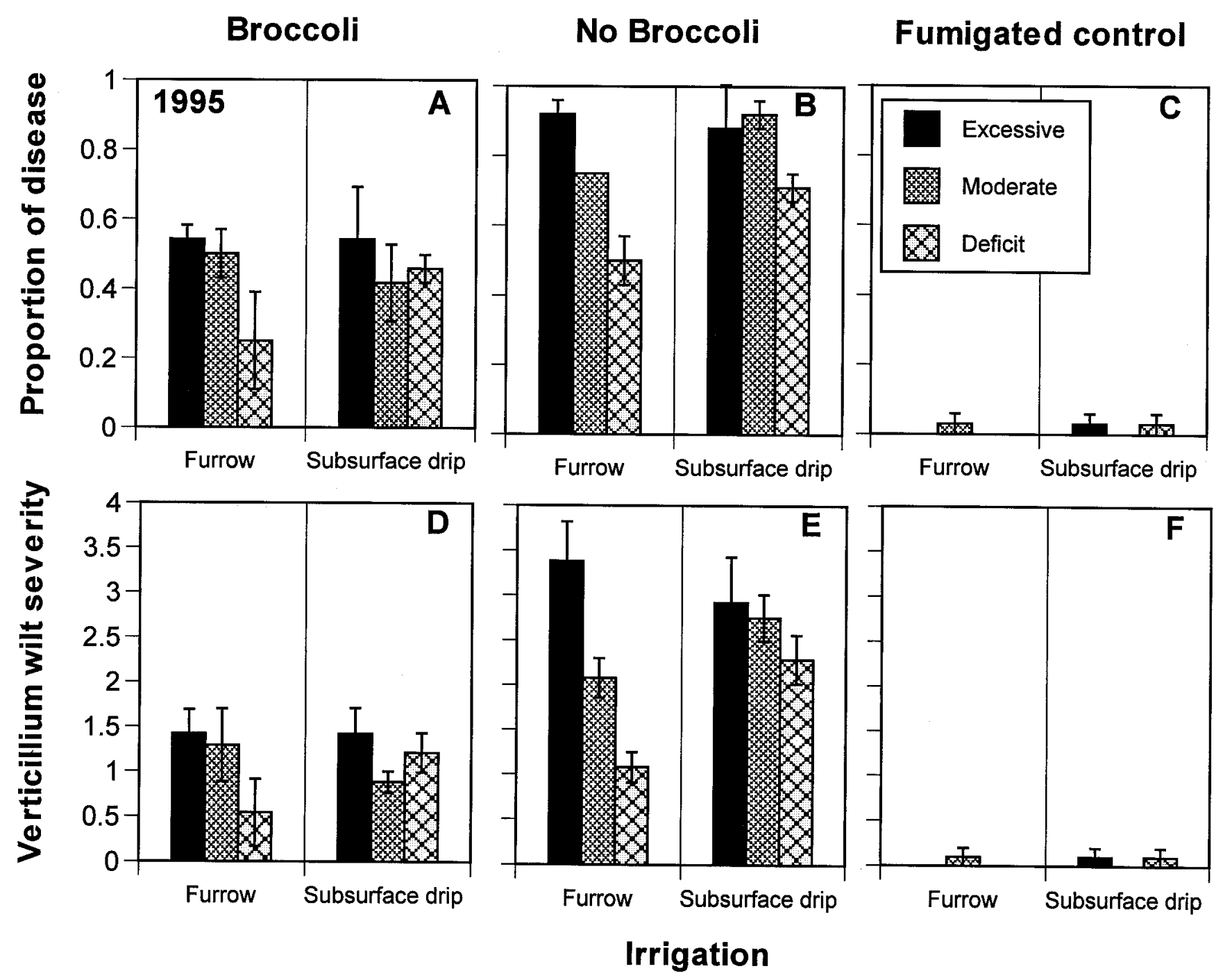

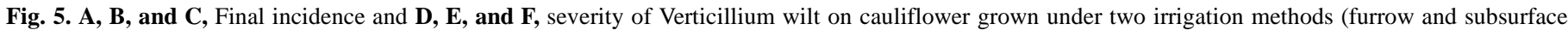

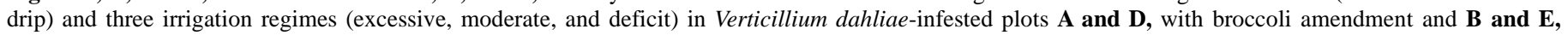

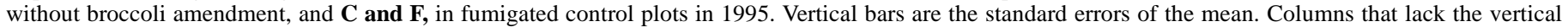
bars have a standard error of 0 . 

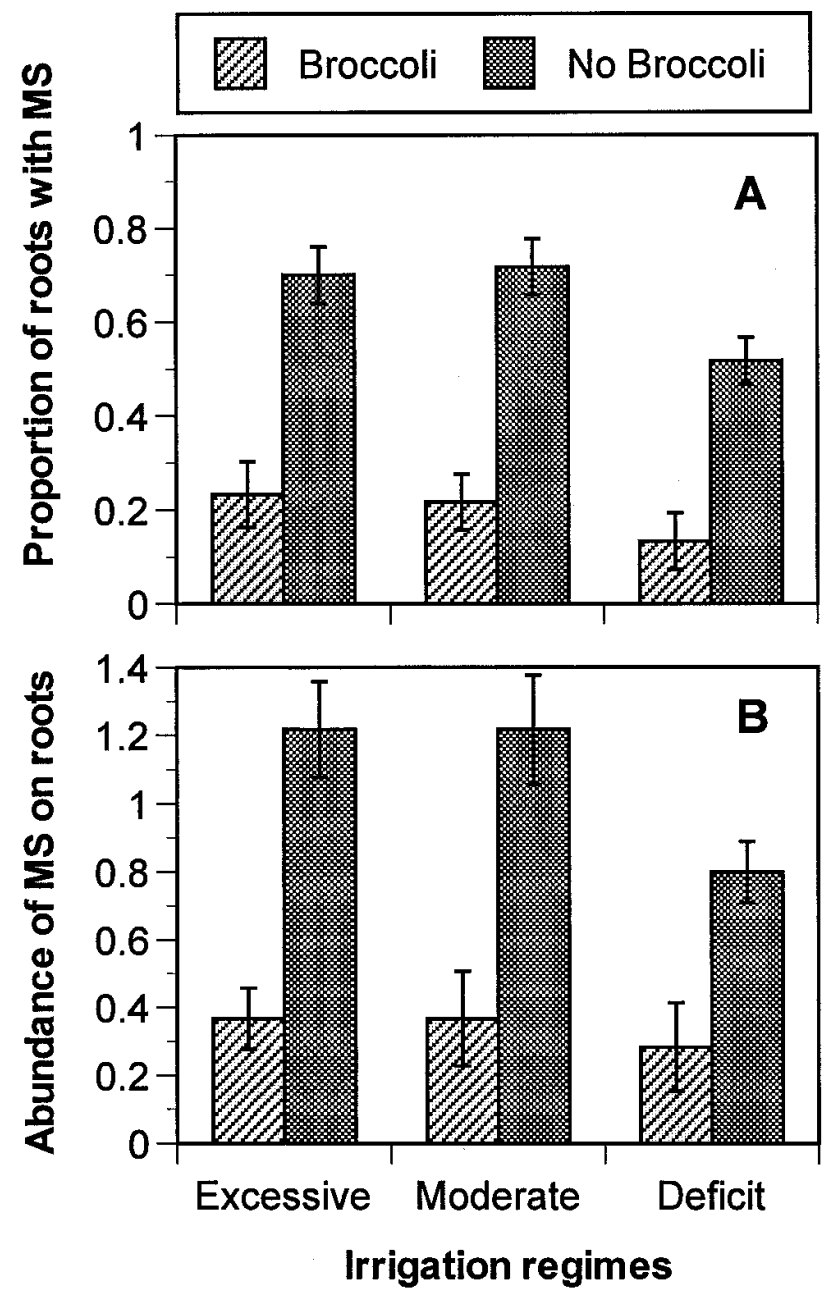

Fig. 6. Effect of broccoli amendment and irrigation regime on A, incidence of cauliflower root system with microsclerotia (MS) and $\mathbf{B}$, abundance of microsclerotia of Verticillium dahliae formed on cauliflower roots 8 weeks after cauliflower harvest in 1994. The abundance of microsclerotia formed on roots was evaluated based on a 0 to 2 rating scale, in which $0=$ no microsclerotia formed on roots, 1 = few microsclerotia formed on roots, and $2=$ abundant microsclerotia formed on roots. Vertical bars are the standard errors of the mean.

soil has been documented $(15,24)$. Other possible mechanisms involved in the long-term reduction of microsclerotia in broccoli treatment may be due to the shift of soil microbial populations. In tomato, the number of microsclerotia produced in infected tomato stems incubated aseptically were four times greater than were those produced during incubation in the presence of soil microflora (19). In our experimental plots after broccoli incorporation, populations of actinomycetes, bacteria, and fungi were significantly higher throughout the cauliflower season in plots with broccoli than in plots with no broccoli (K. V. Subbarao, unpublished data), indicating a possible role for these microflora in inoculum attrition.

Petiole nutrient analyses of potato plants infected by $V$. dahliae under different irrigation regimes did not reveal any association between Verticillium wilt and nutrient deficiency (4). In this study, the nitrate concentration in cauliflower petioles was not significantly different among irrigation regimes in 1994 and was significantly higher in deficit than both excessive and moderate irrigation regimes in 1995. All nitrate levels were, however, within recommended ranges for cauliflower growth (1). Increased wilt severity under the excessive irrigation regime was not related to deficient or surplus nitrate concentration in the petiole.

In summary, incorporation of broccoli residue can reduce the number of $V$. dahliae propagules in soil and incidence and severity of Verticillium wilt on cauliflower regardless of the irrigation methods practiced. Irrigation frequency and amount of water applied did not account for the difference in population changes of $V$. dahliae propagules in soil. Developing rotations with broccoli and incorporating broccoli residue into the soil can be a novel means to control Verticillium wilt on cauliflower and perhaps on other susceptible crops.

\section{ACKNOWLEDGMENTS}

The research was supported, in part, by the California cauliflower growers. We thank B. Mackey for suggestions on the data analyses; S. Benzen, T. Gonzales, J. Hao, J. Hubbard, M. Lepe, R. Liebhard, J. Mcbride, E. Oakes, L. Stevens, M. Rooney, and M. Vidauri for assistance; Natividad Nursery in Salinas for providing broccoli and cauliflower transplants; and M. L. Powelson for the fine presubmission review of this manuscript.

\section{LITERATURE CITED}

1. Anonymous. 1992. Integrated Pest Management for Cole Crops and Lettuce. Statewide Integrated Pest Management Project, University of California, Davis.

2. Butterfield, E. J., and DeVay, J. E. 1977. Reassessment of soil assays for Verticillium dahliae. Phytopathology 67:1073-1078.

3. Café-Filho, A. C., Duniway, J. M., and Davis, R. M. 1995. Effects of the frequency of furrow irrigation on root and fruit rots of squash caused by Phytophthora capsici. Plant Dis. 79:44-48.

4. Cappaert, M. R., Powelson, M. L., Christensen, N. W., and Crowe, F. J. 1992. Influence of irrigation on severity of potato early dying and tuber yield. Phytopathology 82:1448-1453.

5. Cappaert, M. R., Powelson, M. L., Christensen, N. W., Stevenson, W. R., and Rouse, D. I. 1994. Assessment of irrigation as a method of managing potato early dying. Phytopathology 84:792-800.

6. Caroselli, N. E. 1957. Verticillium wilt of maples. R.I. Univ. Agric. Exp. Stn. Bull. 335:1-84.

7. Chan, M. K. Y., and Close, R. C. 1987. Aphanomyces root rot of peas. 3. Control by the use of cruciferous amendments. N.Z. J. Agric. Res. 30:225-233.

8. Davis, J. R., and Everson, D. O. 1986. Relation of Verticillium dahliae in soil and potato tissue, irrigation method, and N-fertility to Verticillium wilt of potato. Phytopathology 76:730-736.

9. Davis, J. R., Huisman, O. C., Westerman, D. T., Hafez, S. L., Everson, D. O., Sorensen, L. H., and Schneider, A. T. 1996. Effects of green manures on Verticillium wilt of potato. Phytopathology 86:444-453.

10. Easton, G. D., Nagle, M. E., and Seymour, M. D. 1992. Potato production and incidence of Verticillium dahliae following rotation to nonhost crops and soil fumigation in the state of Washington. Am. Potato J. 69:489-502.

11. El-Zik, K. M. 1985. Integrated control of Verticillium wilt of cotton. Plant Dis. 69:1025-1032.

12. Farley, J. D., Wilhelm, S., and Snyder, W. C. 1971. Repeated germination and sporulation of microsclerotia of Verticillium albo-atrum in soil. Phytopathology 61:260-264.

13. Feld, S. J., Menge, J. A., and Stolzy, L. H. 1990. Influence of drip and furrow irrigation on Phytophthora root rot of citrus under field and greenhouse conditions. Plant Dis. 74:21-27.

14. Ferrin, D. M., and Mitchell, D. J. 1986. Influence of soil water status on the epidemiology of tobacco black shank. Phytopathology 76:1213-1217.

15. Gamliel, A., and Stapleton, J. J. 1993. Characterization of antifungal volatile compounds evolved from solarized soil amended with cabbage residues. Phytopathology 83:899-905.

16. Gaudreault, S. M., Powelson, M. L., Christensen, N. W., and Crowe, F. J. 1995. Soil water pressure and Verticillium dahliae interactions on potato. Phytopathology 85:1542-1546.

17. Green, R. J., Jr. 1980. Soil factors affecting survival of microsclerotia of Verticillium dahliae. Phytopathology 70:353-355.

18. Huisman, O. C., and Ashworth, L. J., Jr. 1976. Influence of crop rotation on survival of Verticillium albo-atrum in soils. Phytopathology 66:978-981.

19. Ioannou, N., Schneider, R. W., Grogan, R. G., and Duniway, J. M. 1977. Effect of water potential and temperature on growth, sporulation, and production of microsclerotia by Verticillium dahliae. Phytopathology 67: 637-644.

20. Joaquim, T. R., Smith, V. L., and Rowe, R. C. 1988. Seasonal variation and effects of wheat rotation on population of Verticillium dahliae Kleb. in Ohio potato field soils. Am. Potato J. 65:439-447.

21. Johnson, C. M., and Ulrich, A. 1959. Analytical methods for use in plant analysis. Berkeley, Univ. Calif. Exp. Stn. Bull. 766.

22. Keinath, A. P. 1996. Soil amendment with cabbage residue and crop rotation to reduce gummy stem blight and increase growth and yield of 
watermelon. Plant Dis. 80:564-570.

23. Koike, S. T., Subbarao, K. V., Gordon, T. R., Davis, R. M., and Hubbard, J. C. 1994. Verticillium wilt of cauliflower in California. Plant Dis. 78: 1116-1121.

24. Mayton, H. S., Olivier, C., Vaughn, S. F., and Loria, R. 1996. Correlation of fungicidal activity of Brassica species with allyl isothiocyanate production in macerated leaf tissue. Phytopathology 86:267-271.

25. Menzies, J. D., and Griebel, G. E. 1967. Survival and saprophytic growth of Verticillium dahliae in uncropped soil. Phytopathology 57:703-709.

26. Mol, L., Scholte, K., and Vos, J. 1995. Effects of crop rotation and removal of crop debris on the soil population of two isolates of Verticillium dahliae. Plant Pathol. 44:1070-1074.

27. Morgan, D. P., and Michailides, T. J. 1992. Cruciferous amendments, chitin, and Paecilomyces lilacinus reduce populations of Verticillium dahliae in soil. (Abstr.) Phytopathology 82:1156.

28. Nelson, R. 1950. Verticillium wilt of peppermint. Mich. State Univ. Agric. Exp. Stn. Tech. Bull. 221:1-259.

29. Powelson, M. L., and Rowe, R. C. 1993. Biology and management of early dying of potatoes. Annu. Rev. Phytopathol. 31:111-126.

30. Ramirez-Villapudua, J., and Munnecke, D. E. 1987. Control of cabbage yellows (Fusarium oxysporum $\mathrm{f}$. sp. conglutinans) by solar heating of soils amended with dry cabbage residues. Plant Dis. 71:217-221.

31. Ramirez-Villapudua, J., and Munnecke, D. E. 1988. Effect of solar heating and soil amendments of cruciferous residues on Fusarium oxysporum f. sp. conglutinans and other organisms. Phytopathology 78:289-295.

32. Ristaino, J. B., Duniway, J. M., and Marois, J. J. 1988. Influence of fre- quency and duration of furrow irrigation on the development of Phytophthora root rot and yield in processing tomatoes. Phytopathology 78: 1701-1706.

33. Schnathorst, W. C. 1981. Life cycle and epidemiology of Verticillium. Pages 81-111 in: Fungal Wilt Diseases of Plants. M. E. Mace, A. A. Bell, and C. H. Beckman, eds. Academic Press, New York.

34. Subbarao, K. V., Chassot, A., Gordon, T. R., Hubbard, J. C., Bonello, P., Mullin, R., Okamoto, D., Davis, R. M., and Koike, S. T. 1995. Host range of Verticillium dahliae from cauliflower and genetic relationships and cross pathogenicities of isolates from different crops. Phytopathology $85: 1105-1112$

35. Subbarao, K. V., and Hubbard, J. C. 1996. Interactive effects of broccoli residue and temperature on Verticillium dahliae microsclerotia in soil and on wilt in cauliflower. Phytopathology 86:1303-1310.

36. Subbarao, K. V., Hubbard, J. C., and Koike, S. T. 1994. Effects of broccoli residue on Verticillium dahliae microsclerotia and wilt incidence in cauliflower. (Abstr.) Phytopathology 84:1092.

37. Tjamos, E. C. 1989. Problems and prospects in controlling Verticillium wilt. Pages 441-456 in: Vascular Wilt Diseases of Plants. E. C. Tjamos and C. Beckman, eds. Springer-Verlag, Berlin.

38. Xiao, C. L., and Subbarao, K. V. 1996. Effects of broccoli residue and irrigation on microsclerotia of Verticillium dahliae in soil and Verticillium wilt of cauliflower. (Abstr.) Phytopathology 86:S27.

39. Xiao, C. L., and Subbarao, K. V. 1997. Physiological effects of irrigation and Verticillium dahliae on cauliflower growth. (Abstr.) Phytopathology 87:S105. 